\title{
Pengaruh Likuiditas, Profitabilitas, Leverage, Ukuran Perusahaan Dan Tingkat Suku Bunga Terhadap Kondisi Financial Distress Pada 12 Perusahaan Manufaktur Yang Terdaftar Di Bursa Efek Indonesia (Periode 2012-2018)
}

\author{
Yoyo Sudaryo ${ }^{1}$, Dyah Purnamasari ${ }^{2}$, Nunung Ayu Sofiati $\left(\right.$ Efi $^{3}{ }^{3}$, Ana Hadiana ${ }^{4}$ \\ ${ }^{1}$ Sekolah Tinggi Ilmu Ekonomi Indonesia Membangun dan UICM-UNBAR \\ Email : y.sudaryo@yahoo.co.id \\ ${ }^{2}$ Universitas Widyatama \\ Email : dyah.purnamasari@widyatama.ac.id \\ ${ }^{3}$ Sekolah Tinggi Ilmu Ekonomi Indonesia Membangun \\ Email : ayusofiati24@gmail.com \\ ${ }^{4}$ Indonesian Institute of Sciences, LIPI \\ Email: anahadiana68@gmail.com
}

\begin{abstract}
Financial distress is a condition in which the company's financial condition is in an unhealthy state, but has not yet experienced bankruptcy. In Indonesia, several manufacturing companies experience financial instability, manufacturing profits tend to fluctuate, and some companies even experience negative operating income in 2010-2016. Financial distress has a great influence where not only the company will suffer losses but also the stakeholders. One way to predict financial distress is by analyzing financial ratios. This study aims to analyze the effect of liquidity, profitability, leverage, company size and interest rates on financial distress. This study uses quantitative research methods that have the characteristics associated with numerical and objective. The independent variables in this study are Liquidity (X1), Profitability (X2), Leverage (X3), Company Size (X4), and Interest Rate (X5) and the dependent variable in this study is Financial Distress $(\mathrm{Y})$. The scale used is the ratio and nominal scale. The results of research and discussion show that in partial testing ( $t$ test), obtained from the tcount for Liquidity (CR) of 4.324 and the tcount for Profitability (ROA) of 2.441 is greater than the table of 1.989 . And the tcount for Company Size is $-4,059$ smaller than the table value of $-1,989$. As for the variable Leverage (DAR) and Interest Rates, it has no effect on Financial Distress. The assessment is obtained from the tcount for Leverage (DAR) of -0.350 and the tcount for the Interest Rate of 1.080 is smaller than the table of 1.989. Whereas in simultaneous testing (F test) Liquidity (CR), Profitability (ROA), Leverage (DAR), Company Size and Interest Rates simultaneously affect the Financial Distress. The coefficient of determination obtained by $48.8 \%$, while the remaining $51.2 \%$ is influenced by other factors that are ignored by the authors in this study.
\end{abstract}

Keywords: Liquidity, Profitability, Leverage, Company Size, Interest Rates, Financial Distress.

\begin{abstract}
ABSTRAK : Financial distress merupakan suatu kondisi dimana keadaan keuangan perusahaan sedang dalam keadaan tidak sehat, tetapi belum sampai mengalami kebangkrutan. Di Indonesia beberapa perusahaan manufaktur mengalami ketidakstabilan keuangan perusahaan, laba perusahaan manufaktur cenderung mengalami fluktuasi, bahkan beberapa perusahaan sampai mengalami laba operasi negatif pada tahun 2010-2016. Financial distress memiliki pengaruh yang besar dimana bukan hanya pihak perusahaan yang akan mengalami kerugian tetapi juga pihak stakeholder. Salah satu cara untuk memprediksi kondisi financial distress adalah dengan melakukan analisis rasio keuangan. Penelitian ini bertujuan untuk menganalisis pengaruh likuiditas, profitabilitas, leverage, ukuran perusahaan dan tingkat suku bunga terhadap kondisi financial distress. Penelitian ini menggunakan metode penelitian kuantitatif yang memiliki ciri khas berhubungan dengan numerik dan bersifat obyektif. Variabel independen dalam penelitian ini adalah Likuiditas (X1), Profitabilitas (X2), Leverage (X3), Ukuran Perusahaan (X4), dan Tingkat Suku Bunga (X5) dan variabel dependen dalam penelitian ini adalah Financial Distress (Y). Skala yang digunakan yaitu skala rasio dan nominal. Hasil penelitian dan pembahasan menunjukkan bahwa dalam pengujian parsial (uji t), didapatkan dari thitung untuk Likuiditas (CR) sebesar 4,324 dan thitung
\end{abstract}


untuk Profitabilitas (ROA) sebesar 2,441 lebih besar dari ttabel sebesar 1,989. Dan nilai thitung untuk Ukuran Perusahaan sebesar -4,059 lebih kecil dari nilai ttabel sebesar -1,989. Sedangkan untuk variabel Leverage (DAR) dan Tingkat Suku Bunga tidak mempunyai pengaruh terhadap Financial Distress. Penilaian tersebut didapat dari thitung untuk Leverage (DAR) sebesar -0,350 dan thitung untuk Tingkat Suku Bunga sebesar 1,080 lebih kecil dari ttabel sebesar 1,989. Sedangkan dalam pengujian simultan (uji F) Likuiditas (CR), Profitabilitas (ROA), Leverage (DAR), Ukuran Perusahaan dan Tingkat Suku Bunga secara simultan berpengaruh terhadap Financial Distress. Adapun nilai koefisien determinasi yang diperoleh sebesar 48,8\%, sedangkan sisanya sebesar 51,2\% dipengaruhi oleh faktor lain yang diabaikan penulis dalam penelitian ini.

Kata Kunci : Likuiditas, Profitabilitas, Leverage, Ukuran Perusahaan, Suku Bunga, Financial Distress.

\section{PENDAHULUAN}

Pada tahun 2015 laju perekonomian global mengalami ketidakstabilan. Menurut IMF (International Monetary Fund) pada Januari 2016, dalam World Economic Outlook, pertumbuhan ekonomi di China mengalami perkembangan dan perlambatan yang lebih cepat dari yang diperkirakan. https://www.voaindonesia.com/a/pertumbuhan-ekonomichin-akan-melambat/2606433.html (Sumber Biro Statistik Nasional China mengatakan, perekonomian China tumbuh 7,4 persen tahun 2014, turun dari 7,7 persen tahun 2013). Hal ini berakibat pada kegiatan impor maupun ekspor di China yang mencerminkan melemahnya investasi dan aktivitas manufaktur. Peristiwa tersebut dapat menyebabkan kekhawatiran kinerja masa depan perekonomian China yang dapat mengalami spillovers ke negara lain melalui perdagangan dan harga komoditas yang melemah. Aktivitas manufaktur dan perdagangan tetap lemah secara global, penurunan dramatis dalam impor di sejumlah pasar berkembang dapat menyebabkan kesulitan perekonomian dan juga membebani perdagangan global.

Sektor industri manufaktur sangat berperan penting dalam perekonomian nasional. Menurut, www.badanpusatstatistik.com sektor industri manufaktur memberikan nilai tambah terbesar diantara sembilan sektor ekonomi lainnya. Hal ini terbukti berdasarkan angka Produk Domestik Bruto (PDB) pada harga konstan 2010, tahun 2014 kontribusi sektor industri manufaktur terhadap perekonomian mencapai $21,02 \%$.

Berdasarkan data dari www.sahamok.com, selama periode 2012-2018 jumlah perusahaan yang terdelisting dari Bursa Efek Indonesia berjumlah 20 perusahaan, diantaranya 8 dari 20 perusahaan yang terdelisting adalah perusahaan manufaktur. Banyak faktor yang menyebabkan perusahaan harus terdelisting dari Bursa Efek Indonesia dan terancam terkena financial distress.

Suatu perusahaan dapat dikategorikan sedang mengalami financial distress dimana jika perusahaan tersebut memiliki kinerja yang menunjukkan laba bersih negatif. Fenomena lain dari financial distress adalah banyaknya perusahaan yang cenderung mengalami kesulitan likuiditas, dimana ditunjukkan dengan semakin turunnya kemampuan perusahaan dalam memenuhi kewajibannya kepada kreditur (Hanifah, 2013) (eprints.undip.ac.id).

Menurut Platt and Platt dalam Fahmi (2015:107) financial distress didefinisikan sebagai tahap penurunan kondisi keuangan perusahaan yang terjadi sebelum kebangkrutan ataupun likuidasi. Financial distress memiliki pengaruh yang besar dimana bukan hanya pihak perusahaan yang akan mengalami kerugian tetapi juga pihak stakeholder. 
Rasio keuangan adalah angka yang diperoleh dari hasil perbandingan dari suatu pos laporan keuangan dengan pos lainnya yang mempunyai hubungan yang relevan dan signifikan (Harahap, 2013:297). Rasio keuangan yang digunakan dalam penelitian ini sebagai acuan memprediksi financial distress adalah rasio likuiditas, profitabilitas, leverage, dan pengukuran tambahan non keuangan yaitu ukuran perusahaan, serta tingkat suku bunga.

Rasio likuiditas merupakan rasio yang menunjukkan hubungan antara kas dengan asset lancar perusahaan dengan kewajiban lainnya dan dapat diukur melalui current ratio (CR) yakni dengan membagi asset lancar dengan kewajiban lancar. Semakin besar perbandingan aktiva lancar dengan hutang lancar semakin tinggi kemampuan perusahaan menutupi kewajiban jangka pendeknya. (Bringham dan Houston, 2010:134).

Rasio profitabilitas merupakan rasio untuk menilai kemampuan perusahaan dalam mencari keuntungan (Kasmir, 2013:196). Pada penelitian ini profitabilitas diukur dengan menggunakan return on asset (ROA) yaitu rasio yang menunjukkan hasil (return) atas jumlah aktiva yang digunakan dalam perusahaan. Semakin besar return on asset (ROA) menunjukkan kinerja keuangan yang semakin baik, karena tingkat kembalian (return) semakin besar. Apabila return on asset (ROA) meningkat, berarti profitabilitas perusahaan meningkat (Kasmir, 2013:201).

Rasio leverage adalah rasio yang menunjukkan seberapa besar kebutuhan dana perusahaan dibelanjai dengan hutang. Pada penelitian ini leverage diukur dengan debt asset ratio (DAR). Debt asset ratio (DAR) adalah rasio hutang dengan total aktiva yang bisa disebut rasio hutang (debt ratio), mengukur prosentase besarnya dana yang berasal dari hutang. Yang dimaksud dengan hutang adalah semua hutang yang dimiliki oleh perusahaan baik hutang jangka pendek maupun hutang jangka panjang. Kreditor lebih menyukai debt ratio yang lebih rendah sebab tingkat keamanan dana menjadi semakin baik (Sutrisno, 2012:218).

Menurut Riyanto (2008:313), ukuran perusahaan menunjukkan besar kecilnya perusahaan yang dapat dilihat dari ranking besar kecilnya modal yang digunakan, total aktiva yang dimiliki, atau total penjualan yang diperoleh. Ukuran perusahaan juga dapat menunjukkan seberapa besar informasi yang terdapat didalamnya, sekaligus mencerminkan kesadaran dari pihak manajemen mengenai pentingnya informasi, baik bagi pihak eksternal perusahaan maupun pihak internal perusahaan. Semakin besar ukuran perusahaan maka semakin banyak pula informasi yang terkandung didalamnya.

Suku bunga merupakan biaya dalam meminjam, dan biasanya berupa persentase dari jumlah yang dipinjam. Di Indonesia suku bunga ditentukan oleh Bank Indonesia sebagai bank sentral. Strategi suku bunga yang di terapkan BI untuk menstabilkan nilai tukar rupiah tidak bisa dilakukan secara terus menerus, mengingat bank perlu menjalankan fungsi intermediasi perbankan secara lebih leluasa dengan tingkat suku bunga yang rendah.

Pada beberapa perusahaan manufaktur yang terdaftar di BEI periode 2012-2018 terjadi penurunan laba operasi perusahaan bahkan ada pula perusahaan yang sampai memiliki laba operasi negatif. Berikut disajikan laba perusahaan manufaktur setiap tahunnya selama 7 tahun. 


\section{Tabel 1.1 Net Profit}

\begin{tabular}{|l|r|r|r|r|r|r|r|}
\hline \multirow{2}{*}{ Indeks } & \multicolumn{10}{|c|}{ Net Profit } \\
\cline { 2 - 8 } & $\mathbf{2 0 1 2}$ & $\mathbf{2 0 1 3}$ & $\mathbf{2 0 1 4}$ & $\mathbf{2 0 1 5}$ & \multicolumn{1}{c|}{$\mathbf{2 0 1 6}$} & $\mathbf{2 0 1 7}$ & \multicolumn{1}{c|}{$\mathbf{2 0 1 8}$} \\
\hline ADMG & 2.819 & 34.437 & 10.863 & $(611)$ & $(25.491)$ & $(22.886)$ & $(22.309)$ \\
\hline ARGO & $(244.579)$ & $(241.058)$ & $(138.823)$ & 415.265 & $(30.333)$ & $(11.021)$ & $(25.344)$ \\
\hline BATA & 4.601 & 4.272 & 5.233 & 3.348 & 5.264 & 9.727 & 3.172 \\
\hline ESTI & 111 & 582 & $(4.667)$ & $(6.671)$ & $(6.389)$ & $(10.485)$ & 3.127 \\
\hline HDTX & 4.287 & 1.293 & 232 & $(16.354)$ & $(7.746)$ & $(26.601)$ & $(29.436)$ \\
\hline IMAS & 33.582 & 80.927 & 66.193 & 60.083 & 597 & $(671)$ & $(746)$ \\
\hline INDR & 26.000 & 8.000 & 1.000 & 1.600 & $(200)$ & 10.100 & 1.500 \\
\hline INTA & 6.213 & 8.991 & 929 & $(18.596)$ & $(5.762)$ & $(23.126)$ & $(14.445)$ \\
\hline LPIN & 1.056 & 846 & 1.241 & 639 & $(704)$ & $(1.359)$ & $(4.789)$ \\
\hline MASA & 13.158 & 6.943 & 320 & 3.601 & $(311)$ & $(27.120)$ & $(6.483)$ \\
\hline PRAS & 2 & 529 & 3.091 & 6.500 & 8.297 & 3.698 & $(2.286)$ \\
\hline SRSN & 732 & 1.787 & 1.263 & 1.192 & 1.088 & 1.155 & 823 \\
\hline
\end{tabular}

Sumber: www.idx.co.id (dalam ribuan USD)

Berdasarkan tabel 1.1 diatas terlihat bahwa penurunan laba operasi terjadi di beberapa perusahaan manufaktur, 12 dari 30 perusahaan mengalami penurunan laba operasi di akhir tahun 2016. Terdapat 8 perusahaan manufaktur diantaranya sampai mengalami laba operasi negatif, diantaranya PT Polychem Indonesia (ADMG), PT Indo Acidatama Tbk (ARGO), PT Panasia Indosyntec Tbk (HDTX), PT Indo Mobil Sukses Internasional Tbk (IMAS), PT Intraco Penta Tbk (INTA), PT Multi Prima Sejahtera Tbk (LPIN), PT Multstrada Prima Sarana Tbk (MASA), dan PT Prima Alloy Steel Tbk (PRAS). Suatu perusahaan yang dikategorikan mengalami financial distress adalah jika perusahaan tersebut mengalami laba operasi negatif selama dua tahun berturut-turut.

\section{METODELOGI}

Metode yang digunakan dalam penelitian ini adalah metode kuantitatif dengan pendekatan metode deskriptif dan verifikatif.

Metode Penelitian kuantitatif menurut Sugiyono (2014:2) adalah "penelitian ilmiah yang sistematis terhadap bagian-bagian dan fenomena serta hubungan-hubungannya".

Menurut Sugiyono (2014:14) yang dimaksud dengan metode analisis deskriptif adalah sebagai berikut: "Metode desriptif analisis adalah statistik yang digunakan untuk menganalisa data dengan cara mendeskripsikan atau menggambarkan data yang telah terkumpul sebagaimana adanya yang mencari hubungan antara dua variabel atau lebih."

Adapun metode verifikatif menurut Hasan (2008: 20) adalah "metode penelitian yang bertujuan unntuk menguji kebenaran sesuatu dalam bidang yang ada sebelumnya".

\section{HASIL PENELITIAN DAN PEMBAHASAN Deskripsi variable}

\section{Analisis Deskriptif Likuiditas}

Berikut adalah rekapitulasi Likuiditas untuk perusahaan manufaktur yang terdaftar di Bursa Efek Indonesia periode 2012 sampai dengan 2018. 
http://ejournal.uicm-unbar.ac.id/index.php/ekonam

Tabel 1.2 Data Likuiditas Periode 2012 - 2018

\begin{tabular}{|l|l|l|l|l|l|l|l|l|l|}
\hline No. & \multicolumn{1}{|c|}{ Emiten } & Index & $\mathbf{2 0 1 2}$ & $\mathbf{2 0 1 3}$ & $\mathbf{2 0 1 4}$ & $\mathbf{2 0 1 5}$ & $\mathbf{2 0 1}$ & $\mathbf{2 0 1 7}$ & $\mathbf{2 0 1 8}$ \\
\hline 1 & & & & & & & \multicolumn{2}{|c|}{} & \\
\hline 2 & PT. Polychem Indonesia Tbk & ADMG & 1,1 & 1,3 & 2,2 & 2,6 & 2,6 & 2,6 & 1,9 \\
\hline 3 & PT Sepatu Bata Tbk & ARGO & 0,62 & 1,04 & 0,79 & 0,67 & 0,41 & 0,294 & 0,313 \\
\hline 4 & PT. Ever Shine Textile Industry & ESTI & 118,5 & 113,5 & 99,9 & 86,3 & 70,7 & 67,5 & 137,9 \\
\hline 5 & PT Panasia Indosyntec Tbk & HDTX & 0,84 & 0,99 & 0,93 & 0,45 & 1 & 0,7 & 0,8 \\
\hline 6 & $\begin{array}{l}\text { PT Indo Mobil Sukses Internasional } \\
\text { Tbk }\end{array}$ & IMAS & 1,07 & 1,36 & 1,23 & 1,09 & 1,03 & 0,93 & 0,92 \\
\hline 7 & PT Indorama Syntethics Tbk & INDR & 1,1 & 1,1 & 1,1 & 1,1 & 1,1 & 1,1 & 1,2 \\
\hline 8 & PT Intraco Penta Tbk & INTA & 108,96 & 83,97 & 86,6 & 73,7 & 76,22 & 86,5 & 87,5 \\
\hline 9 & PT Multi Prima Sejahtera Tbk & LPIN & 252 & 289 & 290 & 248 & 2,2 & 0,8 & 0,7 \\
\hline 10 & PT. Multistrada Arah Sarana Tbk & MASA & 67 & 48 & 139 & 157 & 175 & 129 & 105 \\
\hline 11 & PT Prima Alloy Steel Tbk & PRAS & 1,45 & 1,14 & 1,11 & 1,03 & 1 & 1 & 1 \\
\hline 12 & PT Indo Acidatama Tbk & SRSN & 242,35 & 317,48 & 275,2 & 328,1 & 287,1 & 216,71 & 174,26 \\
& & & & 1 & 3 & & & \\
\hline
\end{tabular}

Sumber: www.idx.co.id

Dari tabel dan gambar di atas dapat diketahui Likuiditas dari tahun 2010 sampai dengan 2016 cenderung mengalami fluktuasi untuk sebagian besar perusahaanperusahaan yang dijadikan sampel penelitian. Untuk Likuiditas yang paling tinggi tahun 2010 dan 2012 dimiliki oleh PT. Multi Prima Sejahtera Tbk (LPIN) dimana tahun 2010 mencapai 252\% dan tahun 2012 sebesar 290\%. Adapun Likuiditas yang paling tinggi tahun 2011, 2013 dan 2014 dicapai oleh PT. Indo Acidatama Tbk (SRSN) yaitu tahun 2011 sebesar 317,48\%, tahun 2013 sebesar 328,13\% dan tahun 2014 sebesar 287,1\%. Selain itu, untuk tahun 2015 dan 2016 yang memperoleh Likuiditas paling tinggi diraih oleh PT. Sepatu Bata Tbk (BATA) yaitu tahun 2015 sebesar 247\% dan tahun 2016 sebesar $257 \%$.

Likuiditas paling rendah tahun 2010, 2012 dan 2014 sampai dengan 2016 dimiliki oleh PT Argo Pantes Tbk (ARGO) dimana tahun 2010 sebesar 0,62\%, tahun 2012 sebesar 0,79\%, tahun 2014 sebesar 0,41\%, tahun 2015 sebesar 0,29\% dan tahun 2016 sebesar 0,31\%. Adapun Likuiditas paling rendah tahun 2011 dan 2013 diraih oleh PT. Panasia Indosyntec Tbk dimana tahun 2011 sebesar 0,99\% dan tahun 2013 sebesar 0,45\%. Untuk lebih jelasnya, berikut adalah hasil statistik deskriptif untuk variabel Likuiditas sebagai berikut:

\section{Tabel 1.3 Statistik Deskriptif Likuiditas}

Descriptive Statistics

\begin{tabular}{|c|c|c|c|c|c|}
\hline & $\mathrm{N}$ & Minimum & Maximum & Mean & Std. Deviation \\
\hline $\begin{array}{l}\text { CR } \\
\text { Valid N (listwise) }\end{array}$ & $\begin{array}{l}84 \\
84\end{array}$ &, 29 & 328,13 & 77,9762 & 100,15955 \\
\hline
\end{tabular}

Hasil analisis deskriptif variabel Likuiditas pada tabel di atas menunjukan bahwa nilai minimum Likuiditas sebesar $0,29 \%$ dan nilai maksimum Likuiditas sebesar $328,13 \%$. Adapun rata-rata dari Likuiditas sebesar 77,98\% dengan tingkat simpangan bakunya sebesar 100,16\%. 


\section{Analisis Deskriptif Profitabilitas}

Berikut adalah rekapitulasi Profitabilitas untuk perusahaan manufaktur yang terdaftar di Bursa Efek Indonesia periode 2012 sampai dengan 2018.

\section{Tabel 1.4. Statistik Deskriptif Profitabilitas}

\begin{tabular}{|l|l|r|r|r|r|}
\hline & \multicolumn{1}{|c|}{ N } & Minimum & Maximum & \multicolumn{1}{c|}{ Mean } & Std. Deviation \\
\hline ROA & 84 & $-18,40$ & 16,00 & 1,2154 & 5,65954 \\
Valid N (listwise) & 84 & & & & \\
\hline
\end{tabular}

Hasil analisis deskriptif variabel Profitabilitas pada tabel di atas menunjukan bahwa nilai minimum Profitabilitas sebesar -18,4\% dan nilai maksimum Profitabilitas sebesar 16\%. Adapun rata-rata dari Profitabilitas sebesar 1,21\% dengan tingkat simpangan bakunya sebesar $5,66 \%$.

\section{Analisis Deskriptif Leverage}

Berikut adalah rekapitulasi Leverage untuk perusahaan manufaktur yang terdaftar di Bursa Efek Indonesia periode 2012 sampai dengan 2018.

\section{Tabel 1.5. Statistik Deskriptif Leverage}

\begin{tabular}{|c|c|c|c|c|c|}
\hline \multicolumn{6}{|c|}{ Descriptive Statistics } \\
\hline & $\mathrm{N}$ & Minimum & Maximum & Mean & Std. Deviation \\
\hline $\begin{array}{l}\text { DAR } \\
\text { Valid N (listwise) }\end{array}$ & $\begin{array}{l}84 \\
84\end{array}$ &, 30 & 93,50 & 26,8689 & 28,16709 \\
\hline
\end{tabular}

Hasil analisis deskriptif variabel Leverage pada tabel di atas menunjukan bahwa nilai minimum Leverage sebesar $0,3 \%$ dan nilai maksimum Leverage sebesar 93,50\%. Adapun rata-rata dari Leverage sebesar $26,87 \%$ dengan tingkat simpangan bakunya sebesar $28,17 \%$.

\section{Analisis Deskriptif Ukuran Perusahaan}

Berikut adalah rekapitulasi Ukuran Perusahaan untuk perusahaan manufaktur yang terdaftar di Bursa Efek Indonesia periode 2012 sampai dengan 2018.

Tabel 1.6 Statistik Deskriptif Ukuran Perusahaan

Descriptive Statistics

\begin{tabular}{|c|c|c|c|c|c|}
\hline & $\mathrm{N}$ & Minimum & Maximum & Mean & Std. Deviation \\
\hline $\begin{array}{l}\text { Size } \\
\text { Valid N (listwise) }\end{array}$ & $\begin{array}{l}84 \\
84\end{array}$ & 6,33 & 20,21 & 12,7950 & 3,55665 \\
\hline
\end{tabular}


Hasil analisis deskriptif variabel Ukuran Perusahaan pada tabel di atas menunjukan bahwa nilai minimum Ukuran Perusahaan sebesar 6,33 dan nilai maksimum Ukuran Perusahaan sebesar 20,21. Adapun rata-rata dari Ukuran Perusahaan sebesar 12,79 dengan tingkat simpangan bakunya sebesar 3,56.

\section{Analisis Deskriptif Tingkat Suku Bunga}

Berikut adalah rekapitulasi Tingkat Suku Bunga untuk perusahaan manufaktur yang terdaftar di Bursa Efek Indonesia periode 2012 sampai dengan 2018.

Tabel 1.7 Statistik Deskriptif Tingkat Suku Bunga

\begin{tabular}{|l|l|r|r|r|r|}
\hline & \multicolumn{1}{|c|}{ N } & Minimum & Maximum & Mean & Std. Deviation \\
\hline BI_Rate & 84 & 5,75 & 7,75 & 6,7857 &, 74156 \\
Valid N (listwise) & 84 & & & & \\
\hline
\end{tabular}

Hasil analisis deskriptif variabel Tingkat Suku Bunga pada tabel di atas menunjukan bahwa nilai minimum Tingkat Suku Bunga sebesar 5,75\% dan nilai maksimum Tingkat Suku Bunga sebesar 7,75\%. Adapun rata-rata dari Tingkat Suku Bunga sebesar 6,79\% dengan tingkat simpangan bakunya sebesar $7,41 \%$.

\section{Analisis Deskriptif Financial Distress}

Berikut adalah rekapitulasi Financial Distress untuk perusahaan manufaktur yang terdaftar di Bursa Efek Indonesia periode 2012 sampai dengan 2018 dan hasil statistik deskriptif untuk variabel Financial Distress

Tabel 1.8 Statistik Deskriptif Financial Distress

Descriptive Statistics

\begin{tabular}{|c|c|c|c|c|c|}
\hline & $\mathrm{N}$ & Minimum & Maximum & Mean & Std. Deviation \\
\hline $\begin{array}{l}\text { Fin_Distress } \\
\text { Valid N (listwise) }\end{array}$ & $\begin{array}{l}84 \\
84\end{array}$ &,- 43 & 1,81 & ,6840 & ,55108 \\
\hline
\end{tabular}

Hasil analisis deskriptif variabel Financial Distress pada tabel di atas menunjukan bahwa nilai minimum Financial Distress sebesar -0,43 dan nilai maksimum Financial Distress sebesar 1,81. Adapun rata-rata dari Financial Distress sebesar 0,68 dengan tingkat simpangan bakunya sebesar 0,55. 
http://ejournal.uicm-unbar.ac.id/index.php/ekonam

\section{Analisis Regresi Berganda}

Tabel 1.9 Hasil Perhitungan Regresi Linier Berganda

Coefficients $^{\mathbf{a}}$

\begin{tabular}{|c|c|c|c|c|c|c|}
\hline \multirow[b]{2}{*}{ Mode } & & \multicolumn{2}{|c|}{ Unstandardized Coefficients } & \multirow{2}{*}{$\begin{array}{c}\begin{array}{c}\text { Standardized } \\
\text { Coefficients }\end{array} \\
\text { Beta }\end{array}$} & \multirow[b]{2}{*}{$\mathrm{t}$} & \multirow[b]{2}{*}{ Sig. } \\
\hline & & B & Std. Error & & & \\
\hline \multirow[t]{6}{*}{1} & (Constant) & 685 & 460 & & 1,491 &, 140 \\
\hline & $\mathrm{CR}$ & 002 &, 001 &, 435 & 4,324 &, 000 \\
\hline & $\mathrm{ROA}$ & 023 &, 009 &, 233 & 2,441 &, 017 \\
\hline & DAR & 001 & ,002 &, 034 & ,350 &, 727 \\
\hline & Size &,- 054 &, 013 &,- 349 & $-4,059$ &, 000 \\
\hline & BI_Rate & 068 &, 062 &, 091 & 1,080 &, 283 \\
\hline
\end{tabular}

a. Dependent Variable: Fin_Distress

Dari output di atas diketahui nilai konstanta dan koefisien regresi sehingga dapat dibentuk persamaan regresi linier berganda sebagai berikut:

$\mathrm{Y}=0,685+0,002 \mathrm{X}_{1}+0,023 \mathrm{X}_{2}+0,001 \mathrm{X}_{3}-0,054 \mathrm{X}_{4}+0,068 \mathrm{X}_{5}$

Persamaan di atas dapat diartikan sebagai berikut:

$\alpha=0,685$ artinya jika variabel Likuiditas (X1), Profitabilitas (X2), Leverage (X3), Ukuran Perusahaan (X4) dan Tingkat Suku Bunga (X5) bernilai nol (0), maka nilai variabel Financial Distress (Y) diperoleh 0,685 .

$\mathrm{B}_{1}=0,002$ artinya setiap penambahan satu satuan variabel Likuiditas $\left(\mathrm{X}_{1}\right)$ dan variabel lainnya konstan, maka akan meningkatkan nilai variabel Financial Distress (Y) sebesar 0,002. Sebaliknya setiap penurunan satu satuan variabel Likuiditas $\left(\mathrm{X}_{1}\right)$ dan variabel lainnya konstan, maka akan menurunkan variabel Financial Distress (Y) sebesar 0,002 .

$B_{2}=0,023$ artinya setiap penambahan satu satuan variabel Profitabilitas $\left(X_{2}\right)$ dan variabel lainnya konstan, maka akan meningkatkan nilai variabel Financial Distress (Y) sebesar 0,023. Sebaliknya setiap penurunan satu satuan variabel Profitabilitas $\left(\mathrm{X}_{2}\right)$ dan variabel lainnya konstan, maka akan menurunkan nilai variabel Financial Distress (Y) sebesar 0,023.

$\mathrm{B}_{3}=0,001$ artinya setiap penambahan satu satuan variabel Leverage $\left(\mathrm{X}_{3}\right)$ dan variabel lainnya konstan, maka akan meningkatkan nilai variabel Financial Distress (Y) sebesar 0,001. Sebaliknya setiap penurunan satu satuan variabel Leverage $\left(\mathrm{X}_{3}\right)$ dan variabel lainnya konstan, maka akan menurunkan nilai variabel Financial Distress $(\mathrm{Y})$ sebesar 0,001 .

$\mathrm{B}_{4}=-0,054$ artinya setiap penambahan satu satuan variabel Ukuran Perusahaan $\left(\mathrm{X}_{4}\right)$ dan variabel lainnya konstan, maka akan menurunkan nilai variabel Financial Distress (Y) sebesar 0,054. 
http://ejournal.uicm-unbar.ac.id/index.php/ekonam

Sebaliknya setiap penurunan satu satuan variabel Ukuran Perusahaan $\left(\mathrm{X}_{4}\right)$ dan variabel lainnya konstan, maka akan meningkatkan nilai variabel Financial Distress $(\mathrm{Y})$ sebesar 0,054.

$\mathrm{B}_{5}=0,068$ artinya setiap penambahan satu satuan variabel Tingkat Suku Bunga $\left(\mathrm{X}_{5}\right)$ dan variabel lainnya konstan, maka akan meningkatkan nilai variabel Financial Distress (Y) sebesar 0,068. Sebaliknya setiap penurunan satu satuan variabel Tingkat Suku Bunga $\left(\mathrm{X}_{5}\right)$ dan variabel lainnya konstan, maka akan menurunkan nilai variabel

\section{Analisis Koefisiensi Korelasi} Financial Distress (Y) sebesar 0,068.

\section{Analisis Pengujian Koefisien Korelasi}

Perhitungan koefisien korelasi yang digunakan dalam penelitian ini adalah menggunakan korelasi Product Moment. Hasil perhitungan untuk koefisien korelasi adalah sebagai berikut:

Tabel 1.10 Hasil Perhitungan Koefisien Korelasi Correlations

\begin{tabular}{|c|c|c|c|c|c|c|c|}
\hline & & $\mathrm{CR}$ & $\mathrm{ROA}$ & DAR & Size & BI_Rate & Fin_Distress \\
\hline CR & $\begin{array}{l}\text { Pearson Correlation } \\
\text { Sig. (2-tailed) } \\
\mathrm{N}\end{array}$ & 84 & $\begin{array}{l}, 421^{* *} \\
000 \\
84\end{array}$ & $\begin{array}{l}, 397 " \\
, 000 \\
84\end{array}$ & $\begin{array}{l}-, 086 \\
, 435 \\
84\end{array}$ & $\begin{array}{l}-, 073 \\
, 509 \\
84\end{array}$ & $\begin{array}{l}, 570^{* *} \\
, 000 \\
84\end{array}$ \\
\hline ROA & $\begin{array}{l}\text { Pearson Correlation } \\
\text { Sig. (2-tailed) } \\
\mathrm{N}\end{array}$ & $\begin{array}{l}421 \\
000 \\
84\end{array}$ & 84 & $\begin{array}{l}-, 037 \\
, 741 \\
84\end{array}$ & $\begin{array}{l}-, 030 \\
, 786 \\
84\end{array}$ & $\begin{array}{l}-, 259^{*} \\
, 017 \\
84\end{array}$ & $\begin{array}{l}, 402 " \\
, 000 \\
84\end{array}$ \\
\hline DAR & $\begin{array}{l}\text { Pearson Correlation } \\
\text { Sig. (2-tailed) } \\
\mathrm{N}\end{array}$ & $\begin{array}{l}397^{* *} \\
000 \\
84\end{array}$ & $\begin{array}{l}-, 037 \\
, 741 \\
84\end{array}$ & $\begin{array}{l}1 \\
84\end{array}$ & $\begin{array}{l}-, 318^{* *} \\
, 003 \\
84\end{array}$ & $\begin{array}{l}-, 004 \\
, 968 \\
84\end{array}$ & $\begin{array}{l}, 308^{* *} \\
, 004 \\
84\end{array}$ \\
\hline Size & $\begin{array}{l}\text { Pearson Correlation } \\
\text { Sig. (2-tailed) } \\
\mathrm{N}\end{array}$ & $\begin{array}{l}-, 086 \\
435 \\
84\end{array}$ & $\begin{array}{l}-, 030 \\
, 786 \\
84\end{array}$ & $\begin{array}{l}-, 318^{* *} \\
, 003 \\
84\end{array}$ & $\begin{array}{l}1 \\
84\end{array}$ & $\begin{array}{l}, 066 \\
, 550 \\
84\end{array}$ & $\begin{array}{l}-, 398^{* *} \\
, 000 \\
84\end{array}$ \\
\hline $\begin{array}{l}\text { BI_Rat } \\
\text { e }\end{array}$ & $\begin{array}{l}\text { Pearson Correlation } \\
\text { Sig. (2-tailed) } \\
\mathrm{N}\end{array}$ & $\begin{array}{l}-, 073 \\
, 509 \\
84\end{array}$ & $\begin{array}{l}-, 259^{*} \\
, 017 \\
84\end{array}$ & $\begin{array}{l}-, 004 \\
, 968 \\
84\end{array}$ & $\begin{array}{l}, 066 \\
, 550 \\
84\end{array}$ & $\begin{array}{l}1 \\
84\end{array}$ & $\begin{array}{l}-, 024 \\
, 826 \\
84\end{array}$ \\
\hline $\begin{array}{l}\text { Fin_Di } \\
\text { stress }\end{array}$ & $\begin{array}{l}\text { Pearson Correlation } \\
\text { Sig. (2-tailed) } \\
\mathrm{N}\end{array}$ & $\begin{array}{l}570^{*} \\
000 \\
84\end{array}$ & $\begin{array}{l}, 402^{*} \\
, 000 \\
84\end{array}$ & $\begin{array}{l}, 308^{* *} \\
, 004 \\
84\end{array}$ & $\begin{array}{l}-, 398^{* \prime} \\
, 000 \\
84\end{array}$ & $\begin{array}{l}-, 024 \\
, 826 \\
84\end{array}$ & 84 \\
\hline
\end{tabular}

Berdasarkan hasil perhitungan di atas, dapat diketahui bahwa besar korelasi 
antara Likuiditas (X1) terhadap Financial Distress (Y) adalah sebesar 0,570. Hal tersebut menunjukan bahwa terdapat korelasi positif yang sedang antara Likuiditas (X1) terhadap Financial Distress (Y). Besaran korelasi antara Profitabilitas (X2) terhadap Financial Distress $(\mathrm{Y})$ adalah sebesar 0,402. Hal tersebut menunjukkan bahwa terdapat korelasi positif yang sedang antara Profitabilitas (X2) terhadap Financial Distress (Y). Besaran korelasi antara Leverage (X3) terhadap Financial Distress (Y) adalah sebesar 0,308 . Hal tersebut menunjukkan bahwa terdapat korelasi positif yang lemah antara Leverage (X3) terhadap Financial Distress (Y). Besaran korelasi antara Ukuran Perusahaan (X4) terhadap Financial Distress (Y) adalah sebesar -0,398. Hal tersebut menunjukkan bahwa terdapat korelasi negatif yang lemah antara Ukuran Perusahaan (X4) terhadap Financial Distress (Y). Besaran korelasi antara Tingkat Suku Bunga (X5) terhadap Financial Distress (Y) adalah sebesar -0,024. Hal tersebut menunjukkan bahwa terdapat korelasi negatif yang sangat lemah antara Tingkat Suku Bunga (X5) terhadap Financial Distress (Y).

\section{Analisis Koefisien Korelasi Berganda}

Perhitungan koefisien korelasi berganda yang digunakan dalam penelitian ini adalah menggunakan output model summary. Hasil Perhitungan untuk koefisien korelasi berganda adalah sebagai berikut:

Tabel 1.11 Hasil Perhitungan Koefisien Korelasi Berganda Model Summary

\begin{tabular}{|l|c|r|r|r|}
\hline Model & $\mathrm{R}$ & \multicolumn{1}{|c|}{ R Square } & $\begin{array}{c}\text { Adjusted R } \\
\text { Square }\end{array}$ & $\begin{array}{c}\text { Std. Error of the } \\
\text { Estimate }\end{array}$ \\
\hline 1 &, $699^{\mathrm{a}}$ &, 488 &, 456 &, 40661 \\
\hline
\end{tabular}

a. Predictors: (Constant), BI_Rate, DAR, ROA, Size, CR

b. Dependent Variable: Fin_Distress

Berdasarkan output model summary di atas diperoleh nilai $\mathrm{R}$ sebesar 0,699. Nilai tersebut menunjukkan arti bahwa Likuiditas (X1), Profitabilitas (X2), Leverage (X3), Ukuran Perusahaan (X4) dan Tingkat Suku Bunga (X5) memiliki hubungan simultan (bersama-sama) terhadap Financial Distress $(\mathrm{Y})$ yang kuat sebesar 0,699 karena berada dalam interval 0,600 - 0,799.

\section{Analisis Koefisien Determinasi}

Dari hasil perhitungan koefisien korelasi di atas, dapat diketahui nilai koefisien determinasi sebagai berikut:

Tabel 1.12 Hasil Perhitungan Koefisien Determinasi Model Summary ${ }^{b}$

\begin{tabular}{|l|c|r|r|r|}
\hline Model & $\mathrm{R}$ & R Square & $\begin{array}{c}\text { Adjusted R } \\
\text { Square }\end{array}$ & $\begin{array}{c}\text { Std. Error of the } \\
\text { Estimate }\end{array}$ \\
\hline 1 &, $699^{\mathrm{a}}$ &, 488 &, 456 &, 40661 \\
\hline
\end{tabular}

a. Predictors: (Constant), BI_Rate, DAR, ROA, Size, CR

b. Dependent Variable: Fin_Distress

Dengan demikian, maka diperoleh nilai koefisien determinasi sebesar 48,8\% yang menunjukkan arti bahwa Likuiditas $\left(\mathrm{X}_{1}\right)$, Profitabilitas $\left(\mathrm{X}_{2}\right)$, Leverage $\left(\mathrm{X}_{3}\right)$, Ukuran 
Perusahaan $\left(\mathrm{X}_{4}\right)$ dan Tingkat Suku Bunga $\left(\mathrm{X}_{5}\right)$ memberikan hubungan simultan (bersama-sama) sebesar $48,8 \%$ terhadap Financial Distress (Y). Sedangkan sisanya sebesar $51,2 \%$ dipengaruhi oleh faktor lain yang diabaikan dalam penelitian ini.

\section{Uji Hipotesis}

\section{Pengujian Hipotesis Parsial (Uji t)}

Uji Hipotesis parsial (Uji t) digunakan untuk mengetahui besarnya pengaruh Likuiditas, Profitabilitas, Leverage, Ukuran Perusahaan dan Tingkat Suku Bunga Terhadap Financial Distress. Hasil perhitungan pengujian parsial adalah sebagai berikut :

Hasil perhitungan pengujian parsial adalah sebagai berikut :

\section{Tabel 1.13 Hasil Perhitungan Pengujian Parsial (Uji t)}

Coefficients $^{\mathrm{a}}$

\begin{tabular}{|c|c|c|c|c|c|c|}
\hline \multirow[b]{2}{*}{ Mode } & & \multicolumn{2}{|c|}{ Unstandardized Coefficients } & \multirow{2}{*}{$\begin{array}{c}\begin{array}{c}\text { Standardized } \\
\text { Coefficients }\end{array} \\
\text { Beta }\end{array}$} & \multirow[b]{2}{*}{$\mathrm{t}$} & \multirow[b]{2}{*}{ Sig. } \\
\hline & & B & Std. Error & & & \\
\hline \multirow[t]{6}{*}{1} & (Constant) &, 685 &, 460 & & 1,491 &, 140 \\
\hline & $\mathrm{CR}$ & 002 &, 001 &, 435 & 4,324 &, 000 \\
\hline & ROA & 023 &, 009 &, 233 & 2,441 &, 017 \\
\hline & DAR & 001 &, 002 &, 034 &, 350 &, 727 \\
\hline & Size &,- 054 &, 013 &,- 349 & $-4,059$ &, 000 \\
\hline & BI_Rate & 068 &, 062 &, 091 & 1,080 &, 283 \\
\hline
\end{tabular}

a. Dependent Variable: Fin_Distress

Dari perhitungan diatas diperoleh nilai $t_{\text {hitung }}$ untuk Likuiditas $\left(\mathrm{X}_{1}\right)$ sebesar 4,324 dan $t_{\text {tabel }} 1$,989. Dikarenakan nilai $t_{\text {hitung }}>t_{\text {tabel }}$, maka $H_{0}$ ditolak, artinya Likuiditas $\left(\mathrm{X}_{1}\right)$ berpengaruh terhadap Financial Distress (Y).

Dari perhitungan di atas diperoleh nilai thitung untuk Profitabilitas $\left(\mathrm{X}_{2}\right)$ sebesar 2,441 dan $t_{\text {tabel }}$ 1,989. Dikarenakan nilai $t_{\text {hitung }}>t_{\text {tabel, }}$ maka $H_{0}$ ditolak, artinya Profitabilitas $\left(\mathrm{X}_{2}\right)$ berpengaruh terhadap Financial Distress $(\mathrm{Y})$.

Dari perhitungan di atas diperoleh nilai $t_{\text {hitung }}$ untuk Leverage $\left(\mathrm{X}_{3}\right)$ sebesar $-0,350$ dan $t_{\text {tabel }} 1$,989. Dikarenakan nilai $-t_{\text {tabel }}<t_{\text {hitung }}<t_{\text {tabel }}$, maka $H_{0}$ diterima, artinya Leverage $\left(\mathrm{X}_{3}\right)$ tidak berpengaruh terhadap Financial Distress $(\mathrm{Y})$.

Dari perhitungan di atas diperoleh nilai $t_{\text {hitung }}$ untuk Ukuran Perusahaan $\left(\mathrm{X}_{4}\right)$ sebesar $-4,059$ dan $-t_{\text {tabel }}-1,989$. Dikarenakan nilai $t_{\text {hitung }}<-t_{\text {tabel, }}$ maka $H_{0}$ ditolak, artinya Ukuran Perusahaan $\left(\mathrm{X}_{4}\right)$ berpengaruh terhadap Financial Distress $(\mathrm{Y})$.

\section{Hasil Pengujian Hipotesis secara Simultan (Uji F)} ANOVA $^{\mathrm{a}}$

\begin{tabular}{|ll|l|l|l|l|l|}
\hline Model & & Sum of Squares & df & Mean Square & F & Sig. \\
\hline 1 & Regression & 12,310 & 5 & 2,462 & 14,892 &, $000^{\mathrm{b}}$ \\
& Residual & 12,896 & 78 &, 165 & & \\
& Total & 25,206 & 83 & & & \\
& & & & & & \\
\hline
\end{tabular}

a. Dependent Variable: Fin_Distress

b. Predictors: (Constant), BI_Rate, DAR, ROA, Size, CR 
Berdasarkan output di atas diketahui nilai $\mathrm{F}_{\text {hitung }}$ sebesar 14,892 dengan p-value (sig) 0,000 . Dengan $\alpha=0,05$ serta derajat kebebasan $v_{1}=78$ (n-k-1) dan $v_{2}=5$, maka di dapat $F_{\text {tabel }}$ 2,33. Dikarenakan nilai $F_{\text {hitung }}>F_{\text {tabel }}(14,892>2,33)$ maka $H_{0}$ ditolak, artinya variabel Likuiditas $\left(\mathrm{X}_{1}\right)$, Profitabilitas $\left(\mathrm{X}_{2}\right)$, Leverage $\left(\mathrm{X}_{3}\right)$, Ukuran Perusahaan $\left(\mathrm{X}_{4}\right)$ dan Tingkat Suku Bunga $\left(\mathrm{X}_{5}\right)$ secara simultan berpengaruh terhadap Financial Distress $(\mathrm{Y})$.

\section{SIMPULAN}

Dari hasil penelitian perihal Pengaruh Likuiditas, Profitabilitas, Leverage, Ukuran Perusahaan, dan Tingkat Suku Bunga Terhadap Kondisi Financial Distress pada Perusahaan Manufaktur Yang Terdaftar di Bursa Efek Indonesia Tahun 2010-2016, didapatkan kesimpulan sebagai berikut:

1. Berdasarkan penelitian yang dilakukan pada Perusahaan Manufaktur di BEI, Likuiditas dari tahun 2010 sampai dengan 2016 cenderung mengalami fluktuasi untuk sebagian besar perusahaan-perusahaan yang dijadikan sampel penelitian. Hasil analisis deskriptif variabel Likuiditas pada tabel di atas menunjukan bahwa nilai minimum Likuiditas sebesar 0,29\% dan nilai maksimum Likuiditas sebesar 328,13\%. Adapun rata- rata dari Likuiditas sebesar 77,98\% dengan tingkat simpangan bakunya sebesar 100,16\%.

2. Berdasarkan penelitian yang dilakukan pada Perusahaan Manufaktur di BEI, Profitabilitas dari tahun 2010 sampai dengan 2016 cenderung mengalami fluktuasi untuk sebagian besar perusahaan-perusahaan yang dijadikan sampel penelitian. Hasil analisis deskriptif variabel Profitabilitas pada tabel di atas menunjukan bahwa nilai minimum Profitabilitas sebesar $-18,4 \%$ dan nilai maksimum Profitabilitas sebesar 16\%. Adapun rata-rata dari Profitabilitas sebesar 1,21\% dengan tingkat simpangan bakunya sebesar 5,66\%.

3. Berdasarkan penelitian yang dilakukan pada Perusahaan Manufaktur di BEI, Leverage dari tahun 2010 sampai dengan 2016 cenderung mengalami fluktuatif untuk sebagian besar perusahaan yang djadikan sampel penelitian. Hasil analisis deskriptif variabel Leverage pada tabel di atas menunjukan bahwa nilai minimum Leverage sebesar $0,3 \%$ dan nilai maksimum Leverage sebesar 93,50\%. Adapun rata-rata dari Leverage sebesar $26,87 \%$ dengan tingkat simpangan bakunya sebesar $28,17 \%$.

4. Berdasarkan penelitian yang dilakukan pada Perusahaan Manufaktur di BEI, Ukuran Perusahaan dari tahun 2010 sampai dengan 2016 cenderung mengalami peningkatan untuk sebagian besar perusahaan yang djadikan sampel penelitian. Hasil analisis deskriptif variabel Ukuran Perusahaan pada tabel di atas menunjukan bahwa nilai minimum Ukuran Perusahaan sebesar 6,33 dan nilai maksimum Ukuran Perusahaan sebesar 20,21. Adapun rata-rata dari Ukuran Perusahaan sebesar 12,79 dengan tingkat simpangan bakunya sebesar 3,56.

5. Berdasarkan penelitian yang dilakukan pada Perusahaan Manufaktur di BEI, Tingkat Suku Bunga dari tahun 2010 sampai dengan 2016 mengalami fluktuatif. Hasil analisis deskriptif variabel Tingkat Suku Bunga pada tabel di atas menunjukan bahwa nilai minimum Tingkat Suku Bunga sebesar 5,75\% dan nilai maksimum Tingkat Suku Bunga sebesar 7,75\%. Adapun rata-rata dari Tingkat Suku Bunga sebesar 6,79\% dengan tingkat simpangan bakunya sebesar 7,41\%.

6. Berdasarkan penelitian yang dilakukan pada Perusahaan Manufaktur di BEI, Financial Distress dari tahun 2010 sampai dengan 2016 cenderung mengalami fluktuatif untuk sebagian besar perusahaan yang dijadikan sampel penelitian. Hasil analisis deskriptif 
variabel Financial Distress pada tabel di atas menunjukan bahwa nilai minimum Financial Distress sebesar -0,43 dan nilai maksimum Financial Distress sebesar 1,81. Adapun ratarata dari Financial Distress sebesar 0,68 dengan tingkat simpangan bakunya sebesar 0,55.

7. Berdasarkan hasil analisis pengujian koefisien korelasi, dapat diketahui bahwa besar korelasi antara Likuiditas (X1) terhadap Financial Distress (Y) adalah sebesar 0,570. Hal tersebut menunjukan bahwa terdapat korelasi positif yang sedang antara Likuiditas (X1) terhadap Financial Distress (Y). Besaran korelasi antara Profitabilitas (X2) terhadap Financial Distress $(\mathrm{Y})$ adalah sebesar 0,402 . Hal tersebut menunjukkan bahwa terdapat korelasi positif yang sedang antara Profitabilitas (X2) terhadap Financial Distress (Y). Besaran korelasi antara Leverage (X3) terhadap Financial Distress (Y) adalah sebesar 0,308. Hal tersebut menunjukkan bahwa terdapat korelasi positif yang lemah antara Leverage (X3) terhadap Financial Distress (Y). Besaran korelasi antara Ukuran Perusahaan (X4) terhadap Financial Distress $(\mathrm{Y})$ adalah sebesar $-0,398$. Hal tersebut menunjukkan bahwa terdapat korelasi negatif yang lemah antara Ukuran Perusahaan (X4) terhadap Financial Distress (Y). Besaran korelasi antara Tingkat Suku Bunga (X5) terhadap Financial Distress $(\mathrm{Y})$ adalah sebesar -0,024. Hal tersebut menunjukkan bahwa terdapat korelasi negatif yang sangat lemah antara Tingkat Suku Bunga (X5) terhadap Financial Distress (Y).

8. Berdasarkan hasil analisis pengujian koefisien korelasi berganda, dapat diketahui bahwa besar korelasi antara Likuiditas (X1), Profitabilitas (X2), Leverage (X3), Ukuran Perusahaan (X4) dan Tingkat Suku Bunga (X5) terhadap Financial Distress (Y) adalah sebesar 0,699. Nilai tersebut menunjukkan arti bahwa Likuiditas (X1), Profitabilitas (X2), Leverage (X3), Ukuran Perusahaan (X4) dan Tingkat Suku Bunga (X5) memiliki hubungan simultan (bersama-sama) terhadap Financial Distress (Y) yang kuat sebesar 0,699 karena berada dalam interval 0,600-0,799.

9. Berdasarkan hasil penelitian pada uji t, Likuiditas, Profitabilitas dan Ukuran Perusahaan mempunyai pengaruh terhadap Financial Distress pada Perusahaan Manufaktur di BEI. Penilaian tersebut didapatkan dari $t$ hitung untuk Likuiditas sebesar 4,324 dan Profitabilitas sebesar 2,441 lebih besar dibandingkan t tabel sebesar 1,989 dan t hitung untuk Ukuran Perusahaan sebesar -4,059 lebih kecil dari -t tabel sebesar - 1,989. Sedangkan untuk variabel Leverage dan Tingkat Suku Bunga tidak mempunyai pengaruh terhadap Financial Distress pada Perusahaan Manufaktur di BEI. Penilaian tersebut didapatkan dari t hitung untuk Leverage sebesar 0,350 dan Tingkat Suku Bunga sebesar 1,080 berada di antara $-t$ tabel sebesar $-1,989$ dan $t$ tabel sebesar 1,989.

10. Berdasarkan hasil penelitian pada uji F, Likuiditas, Profitabilitas, Leverage, Ukuran Perusahaan, dan Tingkat Suku Bunga secara bersama-sama berpengaruh terhadap Financial Distress pada Perusahaan Manufaktur di BEI. Penilaian tersebut didapatkan dari $\mathrm{F}$ hitung sebesar 14,892 lebih besar dari $\mathrm{F}$ tabel sebesar 2,33 sehingga disimpulkan $\mathrm{H}_{0}$ ditolak karena sesuai dengan ekspektasi penelitian. Adapun nilai koefisien determinasi sebesar 48,8\% yang menunjukkan arti bahwa Likuiditas, Profitabilitas, Leverage, Ukuran Perusahaan, dan Tingkat Suku Bunga memberikan hubungan simultan (bersama-sama) sebesar 48,8\% terhadap Financial Distress. Sedangkan sisanya sebesar 51,2\% dipengaruhi oleh faktor lain yang diabaikan dalam penelitian ini

\section{DAFTAR PUSTAKA}

Agus, R. Sartono. 2010. Manajemen Keuangan Teori dan Aplikasi. Edisi Keempat. Yogyakarta: BPFE. 
Bringham, Eugene F dan Joel F Houston. 2010. Dasar-dasar Manajemen Keuangan. Jilid Pertama. Jakarta: Salemba Empat.

Fahmi, Irham. 2011. Analisis Laporan Keuangan. Bandung: Alfabeta. Harnanto. 2004. Analisa Laporan Keuangan. Yogyakarta: UPD AMP, YKPN. Hasan, Iqbal.2012 Analisis Data Penelitian dengan Statistik. Cetakan Ketiga. Jakarta : Bumi Aksara.

Jogiyanto, Hartono. 2007. Teori Portofolio dan Analisis Investasi (Edisi 5), Yogyakarta: BPFE.

Kasmir. 2013. Analisis Laporan Keuangan. Jakarta: Rajawali Pers.

Machfoedz, Mahmud. 2005. Pengantar Pemasaran Modern. Yogyakarta:UPP AMP YKPN.

Rodoni, Ahmad dan Herni Ali. 2010. Manajemen Keuangan. Jakarta: Mitra Wacana Media.

Riyanto, Bambang. 2008. Dasar-dasar Pembelanjaan Perusahaan. Edisi Keempat. Yogyakarta: BPFE

Rodoni, Ahmad dan Herni Ali. 2010. Manajemen Keuangan. Jakarta: Mitra Wacana Media.

Sugiyono, 2014. Metode Penelitian Kuantitatif, Kalitatif, dan RED. Bandung: Alfabeta.

Sutrisno. 2012. Manajemen Keuangan, Teori, Konsep, dan Aplikasi. Edisi Kedelapan. Yogyakarta: Ekonisia.

\section{Website}

https://www.voaindonesia.com/a/pertumbuhan-ekonomi-chin-akan-melambat/ 2606433.html

www.idx.co.id

www.sahamok.com

www.badanpusatstatistik.com

www.bi.go.id 